Gut, 1968, 9, 57-68

\title{
Clinical data and characteristics differentiating types of peptic ulcer
}

\author{
K. T. VESELÝ, Z. KUBÍČKOVÁ, AND M. DVOŘ́̃KOVÁ \\ with the statistical assistance of K. ZVOLÁNKOVÁ \\ From the Institute of Human Nutrition, Prague, and the Institute of Haematology and \\ Blood Transfusion, Prague
}

The widespread incidence of peptic gastroduodenal ulcer represents a social and economic factor of some consequence. Over the last 100 years much attention has therefore been devoted to the subject, but not even on the fundamental questions of the origin and essential nature of ulcers has agreement been reached. The cause lies in the considerable variability of the clinical manifestations and characteristics of the disease in individual patients.

Observers are particularly struck by the varying incidence of the disease, changing not only according to locality, and to the age, social, and possibly racial composition of the population, but also with time (cohort phenomenon) (Billington, 1965; Demole and Ulman, 1964; Lazarus, 1964; Mašek, 1956; May, 1958; Schade, 1958; Straub and Schornagel, 1958; Susser and Stein, 1962; Watkinson, 1960). In the clinical manifestations and signs (characteristics), too, we find great variety, while the differences are too deep-seated to be capable of explanation in terms of divergencies in the localization and extent of the lesions. Some authors have come to the conclusion that duodenal and gastric ulcers are two independent diseases (Frankel and Kark, 1965; Shay and Sun, 1964; Wilson, 1962). Although this idea is unlikely to meet with general acceptance, differences in the incidence of some signs, especially the genetically conditioned, suggest the need for effective grouping of the clinical types of peptic ulcer, because the overall evaluation of the incidence of signs in ulcer conditions as a whole inevitably leads to confused or, indeed, contradictory conclusions, according to which type of ulcer has been prevalent in a given set. The customary use of topical classification is not, however, suitable, since it fails to take into account the dynamics of the condition, which may progressively affect various sections of the alimentary system, and apparently does not even respect certain aetiological factors.

Probably for no other disease have so many versions and theories of origin been advanced as for peptic ulcer. This is because the separate factors and conditions, which are undoubtedly important, but not in all cases essential links in the complicated pathogenetic process, have been elevated to the status of sole causes of ulcer formation. A more thorough insight into the nature of the disease and a more exact distinction of individual types of ulcer is of vital significance for effective treatment and prevention. The present work is directed to this end.

\section{MATERIAL AND METHODS}

The work is based on the collection of data and characteristics concerning patients and on the analysis and statistical evaluation of the results. The basic survey comprises 1,160 patients of the Institute of Human Nutrition, and moreover it contains data about further patients from various institutes in Prague.

The aim was (1) to gain as much information as possible on the epidemiology and symptomatology of gastroduodenal ulcers and on any laws by which the condition may be governed; (2) to ascertain the different features of types of ulcer and in the light of the results suggest the best method for their classification; (3) to follow the mutual relationships among clinical signs and characteristics; and (4) to contribute as far as possible to the study of the aetiology of the condition.

\section{RESULTS}

INCIDENCE AND DISTRIBUTION OF TYPES OF GASTRODUODENAL ULCER In the light of our preliminary experience (Kubíčková and Veselý, 1966; Veselý, 1964, 1966) we divided patients with peptic ulcers into three groups, those with duodenal, combined, and primary gastric ulcers. The combined ulcer started as a duodenal and after a time there appeared (rarely concurrently, or more often after healing of the original lesion) a gastric ulcer, too; the reverse process has never been reliably demonstrated. Patients with this type of ulcer were all admitted and treated for gastric lesions. 
Table I indicates that of the total number of patients with gastric ulcers (both combined and primary gastric ulcers), $41 \cdot 18 \%$ had a duodenal ulcer in their case histories, and on the contrary, in $18.23 \%$ with duodenal ulcers, the appearance of gastric ulcers can be expected in later years.

TABLE I

INCIDENCE OF DIFFERENT TYPES OF ULCER IN THE INVESTIGATED GROUP

\begin{tabular}{lccc} 
Sex & \multicolumn{3}{l}{ Ulcer } \\
\cline { 2 - 4 } & Duodenal & Combined & Primary Gastric \\
\hline & 752 & 168 & 240 \\
Males & 572 & 124 & 164 \\
Females & 180 & 44 & 76 \\
Ratio & $3 \cdot 16$ & $2 \cdot 82$ & $2 \cdot 16$
\end{tabular}

In localizing the gastric lesions in relation to the angulus, there was a significant difference between combined and primary gastric ulcers; localization of the lesion below the angulus was more frequent in combined ulcers (Table II).

TABLE II

SITE OF GASTRIC LESION IN COMBINED AND PRIMARY GASTRIC ULCERS

\begin{tabular}{lcccc} 
Ulcers & Below the Angulus & Above the Angulus & $\chi^{2}$ & $P$ \\
\hline $\begin{array}{l}\text { Combined } \\
\text { Primary } \\
\text { gastric }\end{array}$ & 74 & 94 & $12 \cdot 3569$ & 0.001 \\
& 67 & 173 & &
\end{tabular}

The onset of the disease, i.e., the age of the patient at the time of the first evidence of an ulcer, is recorded in Figure 1. In duodenal ulcers, the size of the group enables the incidence to be recorded by sex, too; no significant difference was found between the two curves.

The average age of patients at the time when lesions appeared was for those with duodenal ulcers $33.4( \pm 10.91)$ and with combined ulcers 36.84 $( \pm 10 \cdot 49)$ years. The values were almost the same for both sexes. The average age of patients at the onset of duodenal ulcers was almost the same for both types of ulcer, but the curve of age distribution for combined ulcers is bimodal. This phenomenon deserves further observation with a larger group of patients.

The average age of patients at the time of the first evidence of gastric lesion was for combined ulcers $47.92( \pm 11.76)$ and for primary gastric ulcers $44.58( \pm 13 \cdot 10)$ years. In the case of combined ulcers, gastric lesions therefore appeared on an average 11 years after the duodenal lesions. For gastric lesions of both types, ulcers below the angulus appeared sooner than above it (Fig. 2 and Table III). The statistically significant difference in the onset of ulcers below the angulus and above it agrees with the conception that the propensity of the mucous membrane for ulcer formation proceeds with age from the duodenum in the oral direction (Lazovskij, 1947; Oi, Oshida, and Sugimura, 1959; Schade, 1958).

Duodenal ulcer - $(752)$ D.U. in combined ulcers -
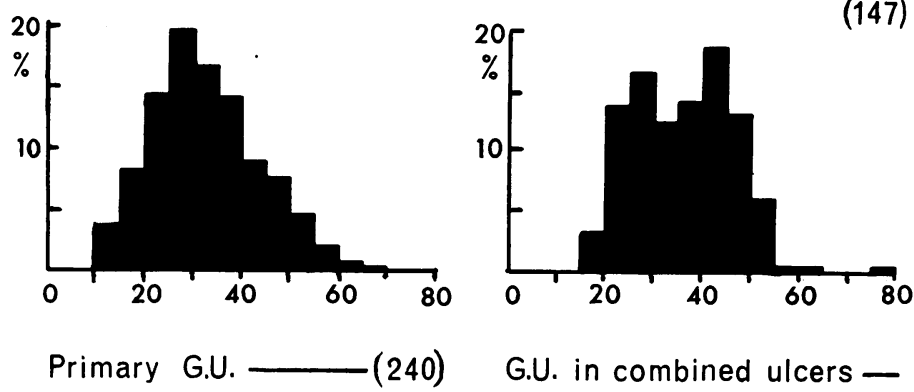

FIG. 1. Age distribution of patients with peptic ulcers at the time when duodenal or gastric lesion was first detected. (Figures in brackets denote number of cases.)

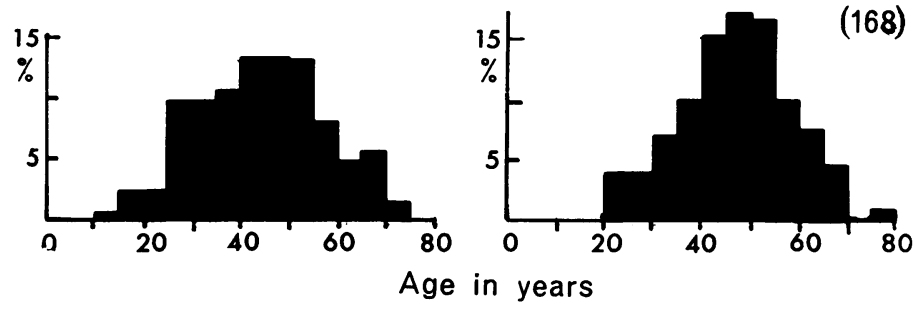

(168) 
Combined ulcer
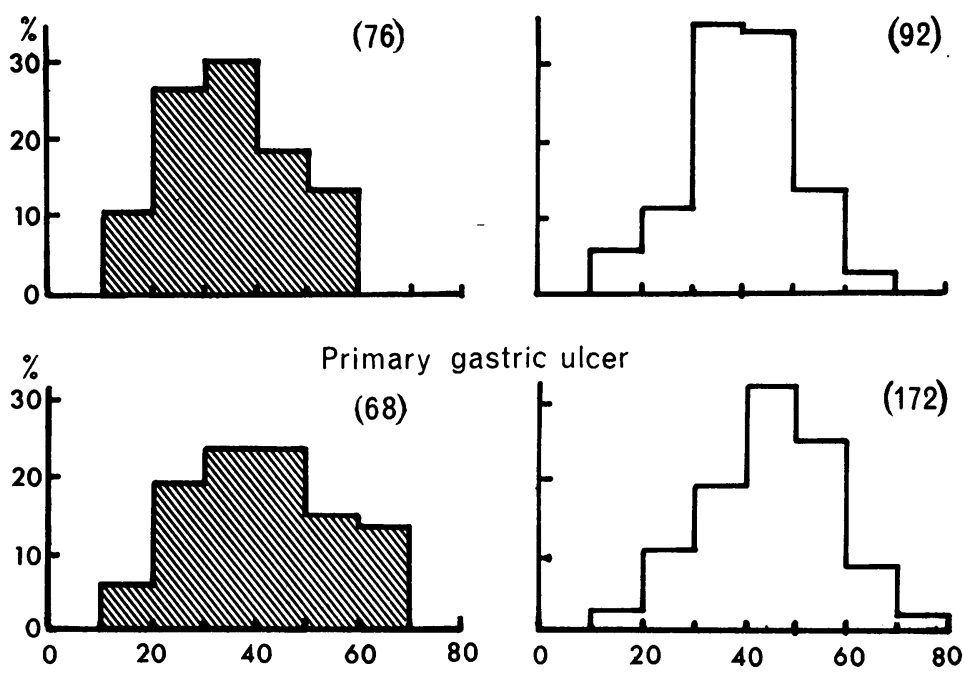

FIG. 2. Age distribution of patients at time when the gastric lesion was first detected and its localization beneath the angulus and above it. (Figures in brackets denote number of cases.)

\section{$\square$ Ulcers above angulus \\ Uicers below angulus}

Published data agree that peptic ulcer is a disease with a family incidence (Hanley, 1964; Jirásek and Gregor, 1964; Kozoll and Meyer, 1964; Levrat, Larbre, and Richard, 1954; McHardy, 1962). According to data obtained from our patients, $25.9 \%$ of patients with duodenal ulcer had close relatives with histories of the disease: for combined ulcer patients it was $23.2 \%$, and for those with primary gastric ulcer $22.1 \%$. Men were affected about two-and-a-half times more frequently than women. In a group of 500 patients treated in our Institute who did not suffer from peptic ulcer or cancer, peptic ulcers were found in the family history in $8 \%$. The difference for all types of ulcers is statistically highly significant.
GASTRIC ACIDITY IN THE TYPES OF GASTRODUODENAL ULCER Hydrochloric acid is considered as one of the most important factors in the origin and course of the ulcer condition, because it raises the aggression of the gastric juices and conditions their peptic activity. Some patients, however, show no increase of the $\mathrm{HCl}$ level and cases even occur where ulcers are accompanied by anacidity. Consequently, some authors postulate the presence of $\mathrm{HCl}$ at least at the time of the origin of the first lesion. Determination of acidity remains a valuable method; using the maximum gastrin or histamine stimulation, the secretory capacity, depending on the mass of the parietal cells, can be determined (Card, 1961). In this respect $\mathrm{HCl}$ is a more sensitive indicator than

TABLE III

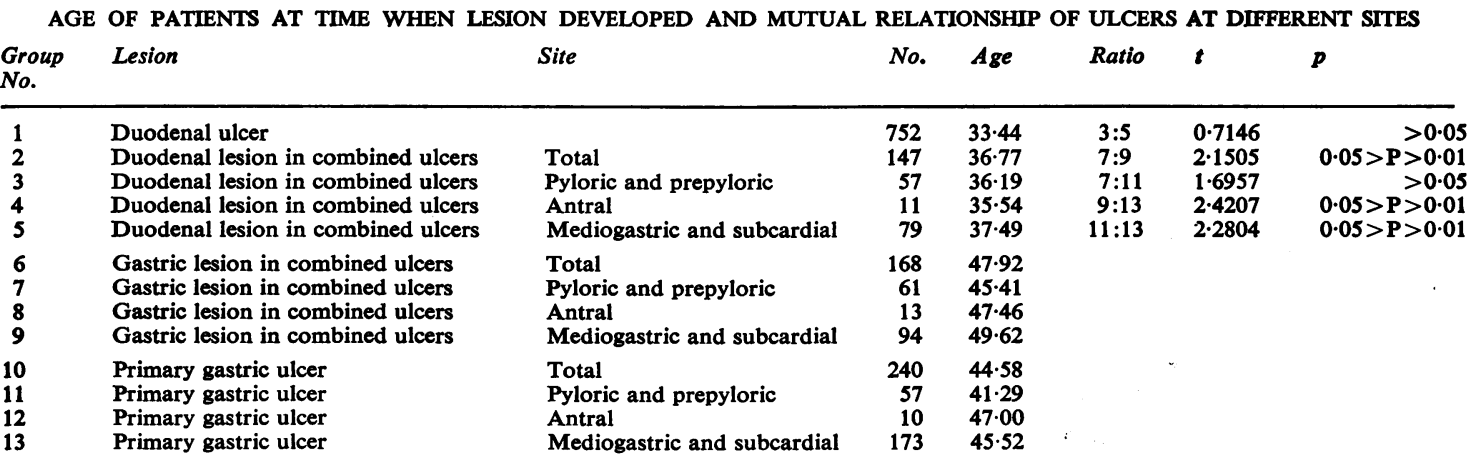



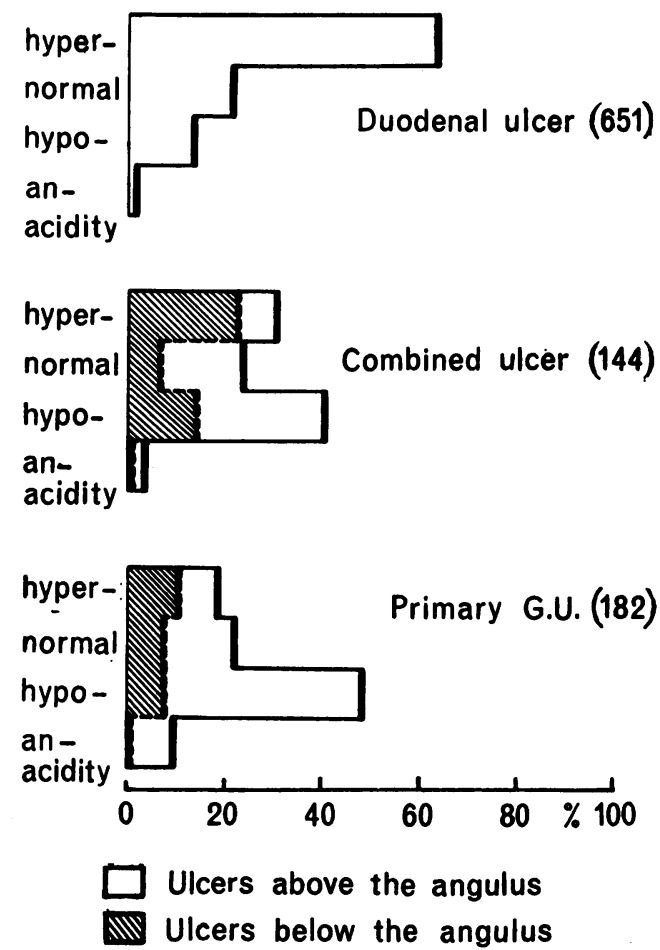

FIG. 3. Distribution of patiens by gastric acidity in different types of ulcer. (Figures in brackets denote number of cases.)

pepsin or intrinsic factor, the secretion of which, more important for preserving vital functions, is maintained longer (Sievers, 1959). An important factor in the genesis of ulcers is also the gastric mucus, its amount and quality (Glass, Stephanson, and Rich, 1956; Gullberg and Olhagen, 1959; Placer, Roubal, and Vokáč, 1958).

Gastric acidity was examined in 980 patients, of whom 651 had duodenal ulcers, 144 combined, and 182 primary gastric ulcers. For technical reasons the examination could not be carried out quantitatively, and $\mathrm{HCl}$ concentration alone was measured. The patients were divided according to four levels of acidity; the limit of hyperacidity was put at 60 units after caffein and 80 after histamine, the limit of hypoacidity below $\mathbf{4 0}$ units.

In duodenal ulcers, hyperacidity prevailed (63\%), in combined and primary gastric ulcers, hypacidity, roughly equally for both types (Fig. 3). From Fig. 3 it is also evident that the localization of the ulcer was decisive in gastric lesions. In ulcers below the angulus, hyper- and normal acidity predominated, while in ulcers placed above it, hypoacidity was to the fore and anacidity was more frequent.
We can, therefore, presume that the secretory capacity, given by the mass of the parietal cells, drops with the progressing (degenerative) changes of the mucosa, so also preparing the ground for ulcer formation. In gastric lesions of equivalent localization, the secretory capacity is at the given stage the same for combined and gastric ulcers. It is also possible to assume that in those duodenal ulcers where this intestinal metaplasia of the mucosa, and consequently a drop in acidity, takes place, a gastric ulcer will also form more frequently.

The relationship between the level of acidity and blood group $\mathrm{O}$ is interesting. Patients with duodenal ulcers having blood group $\mathbf{O}$ showed a more frequent incidence of higher acid levels than those with other blood groups; this difference was statistically significant (Table IV).

TABLE IV

GASTRIC ACIDITY AND BLOOD GROUPS IN PATIENTS WITH DUODENAL ULCERS

\begin{tabular}{|c|c|c|c|c|c|}
\hline $\begin{array}{l}\text { Blood } \\
\text { Groups }\end{array}$ & $\begin{array}{l}\text { Hyper and } \\
\text { Normal Acidity }\end{array}$ & Total & $\begin{array}{l}\text { Per- } \\
\text { centage }\end{array}$ & $x^{2}$ & $\boldsymbol{P}$ \\
\hline $\mathbf{O}$ & 174 & 195 & $89 \cdot 23$ & 0.5054 & 0.005 \\
\hline $\begin{array}{l}\text { Other } \\
\text { A }\end{array}$ & $\begin{array}{l}239 \\
154\end{array}$ & $\begin{array}{l}303 \\
189\end{array}$ & $\begin{array}{l}78 \cdot 8 \\
81 \cdot 48\end{array}$ & & \\
\hline Other & 259 & 309 & $83 \cdot 82$ & 0.5435 & $0.50>P>0.40$ \\
\hline
\end{tabular}

RELATIONSHIP BETWEEN BLOOD GROUPS OF THE ABO AND RHo (D) SYSTEMS AND PEPTIC GASTRODUODENAL ULCER Reports in the world literature on the distribution of blood groups among patients with ulcer disease are very varying and often quite contradictory (Aird, 1959; Buckwalter, 1962; Doll, Drane, and Newell, 1961). Only recently it has been realized that the type of ulcer is important, and the need for a good classification of ulcer types has become especially urgent (Clarke, 1959; Kubíčková and Veselý, 1966). The majority of authors find a predominance of group $\mathbf{O}$ among duodenal ulcer patients; some indicate a slight prevalence of group A with gastric ulcers. The question of the genetic linkage, blood group-ulcer, has not been elucidated; among patients with duodenal ulcers, however, an increased number of parietal cells is usually shown and sometimes, as in our material, hyperacidity, too.

The blood group was assessed in 1,964 patients suffering from ulcer disease who live in Prague or its nearest surroundings. For comparison a survey of 1,142 Prague inhabitants was used (Kout, 1959).

Figure 4 illustrates the frequency of blood groups for our three types of ulcer. It shows that while for primary gastric ulcers the blood group distribution 


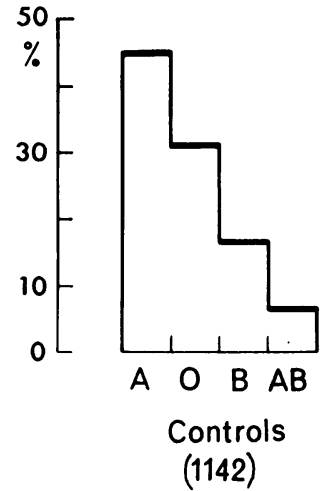

is the same as for the controls, for duodenal ulcers groups $\mathrm{O}$ and $\mathrm{AB}$ are more frequent, at the expense of group A. Similarly, group O predominates for combined ulcers, too. Statistical evaluation of these relationships is given in Table V. In agreement with published results, no difference was found in the case of system $\mathrm{Rh}_{0}$ (D) as against the controls for any kind of ulcer. Nor was any difference found between the sexes. From the above figures it can be calculated that the probability of contracting a duodenal ulcer is $35 \%$ higher for people of blood groups $\mathrm{O}$ and $\mathrm{AB}$ than the other groups, and on the contrary, it is lower for group A by $25.5 \%$ and for group $B$ by $12.5 \%$.

RELATIONSHIPS BETWEEN ULCER CONDITIONS AND SECRETOR STATUS OF ABH BLOOD GROUP SUBSTANCES As with the distribution of blood groups of the ABO system, an examination was also made of the relationships between secretion of water-soluble ABH group substances in patient's saliva and peptic ulcers. Here, too, varying relationships were observed for the different types of ulcer (Buckwalter, 1962; Caldwell and Pigman, 1965; Clarke, 1959; Doll et al., 1961 ; Langman and Doll, 1965; McConnell, 1960; Newman, Naifeh, Auer, and Buckwalter, 1961; Roberts, 1957). Most authors agree that patients with duodenal ulcer show a higher percentage of non-secretors of these substances, and they assume certain genetic relationships or a linkage. The nature of the connexion is unknown; the possibility is not excluded that the substances have a protective effect on the duodenal mucosa (McConnell, 1960). The secretor status is independent of the blood group (Caldwell and Pigman, 1965), which does not exclude a possible

TABLE V

FREQUENCY OF BLOOD GROUPS IN PATIENTS WITH DUODENAL (D), COMBINED (C), AND GASTRIC (G) ULCERS COMPARED WITH PRAGUE POPULATION

\begin{tabular}{|c|c|c|c|c|c|c|}
\hline Type of Ulcer & Cases & & & & $\sim^{2}$ & \\
\hline & Patients & & Controls & & & \\
\hline & $A$ & $O, B, A B$ & $A$ & $O, B, A B$ & & \\
\hline D & 496 & 808 & 516 & 626 & $12 \cdot 9008$ & -0.001 \\
\hline C & 86 & 110 & 516 & 626 & $0 \cdot 1861$ & $>0.05$ \\
\hline G & $\begin{array}{l}214 \\
O\end{array}$ & $\begin{array}{l}250 \\
\text { Other groups }\end{array}$ & $\begin{array}{l}516 \\
O\end{array}$ & $\begin{array}{l}626 \\
\text { Other groups }\end{array}$ & $0 \cdot 1175$ & $>0.05$ \\
\hline D & 497 & 807 & 358 & 784 & $12 \cdot 3814$ & -0.001 \\
\hline C & 80 & 116 & 358 & 784 & $6 \cdot 7753$ & $0.01>P>0.001$ \\
\hline $\mathbf{G}$ & 149 & 315 & 358 & 784 & 0.0877 & $>0.05$ \\
\hline & $B$ & Other groups & $B$ & Other groups & & \\
\hline D & 195 & 1,109 & 191 & 951 & $1 \cdot 4416$ & $>0.05$ \\
\hline C & 22 & 174 & 191 & 951 & $1 \cdot 1988$ & $>0.05$ \\
\hline G & 68 & 296 & 191 & 951 & 0.7418 & $>0.05$ \\
\hline & $A B$ & Other groups & $A B$ & Other groups & & \\
\hline D & 116 & 1,188 & 77 & 1,065 & $3 \cdot 8783$ & $0.05>P>0.01$ \\
\hline C & 12 & 184 & 77 & 1,065 & 0.0964 & $>0.05$ \\
\hline $\mathbf{G}$ & 33 & 431 & 77 & 1,065 & 0.0683 & $>0.05$ \\
\hline D & 1,090 & 214 & 768 & 166 & 0.6383 & $>0.05$ \\
\hline C & 158 & 38 & 768 & 166 & $0 \cdot 1546$ & $>0.05$ \\
\hline $\mathbf{G}$ & 393 & 71 & 768 & 166 & 1.4639 & $>0.05$ \\
\hline
\end{tabular}


correlation (cooperation) of the two factors in ulcer formation.

Secretor status was examined in 658 patients, of whom 442 had duodenal, 54 combined, and 162 primary gastric ulcers. As a control group, 1,349 inhabitants from Prague, who do not suffer from peptic ulcer (Kubičková and Dvořáková, unpublished), were examined.

The percentage of non-secretors was increased among ulcer patients, to the greatest degree among those with duodenal and combined, slightly in those with gastric, ulcers. This increase is statistically significant for duodenal ulcers, not significant for the primary gastric; the size of the group was too small in the case of combined ulcers (Table VI).

We also followed up the secretor status in our group in relation to the distribution of blood groups of the ABO system among patients (Table VII). The number of non-secretors was higher among

\section{TABLE VI}

SECRETOR STATUS OF ABH BLOOD GROUP SUBSTANCES IN PATIENTS WITH DIFFERENT TYPES OF ULCER AS COMPARED WITH DATA FOR PRAGUE POPULATION

\begin{tabular}{|c|c|c|c|c|c|}
\hline \multirow[t]{2}{*}{ Type of Ulcer } & \multicolumn{2}{|c|}{ Patients } & \multirow{2}{*}{$\begin{array}{l}\text { Controls } \\
\text { Percentage } \\
\text { Non-secretors }\end{array}$} & \multirow[t]{2}{*}{$\chi^{2}$} & \multirow[t]{2}{*}{$\boldsymbol{P}$} \\
\hline & No. & $\begin{array}{l}\text { Percentage } \\
\text { Non-secretors }\end{array}$ & & & \\
\hline $\begin{array}{l}\text { Duodenal } \\
\text { Combined } \\
\text { Primary }\end{array}$ & $\begin{array}{r}442 \\
54\end{array}$ & $\begin{array}{l}36.04 \\
29.6\end{array}$ & $\begin{array}{l}25 \cdot 08 \\
25 \cdot 08\end{array}$ & $\begin{array}{r}19 \cdot 2477 \\
0.5454\end{array}$ & $\begin{array}{l}<0.001 \\
>0.05\end{array}$ \\
\hline gastric & 162 & 26.5 & $25 \cdot 08$ & 0.1518 & $>0.05$ \\
\hline
\end{tabular}

duodenal ulcer patients of all groups. Non-secretors of ABH group substances, therefore, show a greater probability of contracting peptic ulcer than the secretors, as follows: duodenal ulcer by $71.1 \%$, combined ulcer by $25.6 \%$, and primary gastric ulcer by $7.7 \%$.

By distribution of blood group $\mathrm{ABO}$, nonsecretors of each blood group show a probability of contracting duodenal ulcers, as opposed to all other groups (i.e. secretors of the given group, and nonsecretors and secretors of all other groups): for group $\mathrm{O}$ is greater by $103 \%$; for group $\mathrm{A}$ by $9.1 \%$; for group $\mathrm{AB}$ by $81.5 \%$; and for group $\mathrm{B}$ by $59.0 \%$.

The role of the group substances is still far from clear, but undoubtedly one can welcome the fact that they direct attention, alongside genetic relationships, to local chemico-physical and immunological conditions possibly playing a part in ulcer formation.

PHENYLTHIOCARBAMIDE (PTC)-TASTE SENSITIVITY IN PATIENTS WITH GASTRODUODENAL ULCERS Over recent decades it has been found that people, and some anthropoids, show varying levels of PTC-taste sensitivity. In view of the fact that this characteristic follows simple laws of heredity, it presents a suitable subject for genetic study and consequently for seeking genetic relationships with ulcer disease. Indeed, with 121 patients suffering from ulcer Kaplan, Fischer, Glanville, Powell, Kamionkowski, and Fleshler (1964) ascertained a lower percentage of non-tasters in patients with duodenal ulcer. We

TABLE VII

SECRETOR STATUS OF ABH BLOOD GROUP SUBSTANCES IN DIFFERENT TYPES OF PEPTIC ULCER WITH REGARD TO BLOOD GROUPS OF THE ABO SYSTEM

Blood Group Type of Ulcer

\begin{tabular}{|c|c|c|c|c|c|c|c|}
\hline & \multicolumn{2}{|c|}{ Duodenal } & \multicolumn{2}{|c|}{ Combined } & \multicolumn{2}{|c|}{ Primary Gastric } & \multirow{2}{*}{$\begin{array}{l}\text { Controls } \\
\text { Percentage of } \\
\text { Non-secretors }\end{array}$} \\
\hline & No. & $\begin{array}{l}\text { Percentage of } \\
\text { Non-secretors }\end{array}$ & No. & $\begin{array}{l}\text { Percentage of } \\
\text { Non-secretors }\end{array}$ & No. & $\begin{array}{l}\text { Percentage of } \\
\text { Non-secretors }\end{array}$ & \\
\hline $\begin{array}{l}\text { A } \\
\text { O } \\
\text { B } \\
\text { AB } \\
\text { Total }\end{array}$ & $\begin{array}{r}171 \\
174 \\
55 \\
42 \\
442\end{array}$ & $\begin{array}{l}34 \cdot 5 \\
36 \cdot 8 \\
36 \cdot 4 \\
42 \cdot 8 \\
36 \cdot 4\end{array}$ & $\begin{array}{r}28 \\
18 \\
5 \\
3 \\
54\end{array}$ & $\begin{array}{c}32 \cdot 1 \\
33 \cdot 3 \\
(100 \cdot 0) \\
(33 \cdot 3) \\
29 \cdot 6\end{array}$ & $\begin{array}{r}76 \\
47 \\
22 \\
17 \\
162\end{array}$ & $\begin{array}{l}22 \cdot 4 \\
28 \cdot 3 \\
31 \cdot 8 \\
35 \cdot 3 \\
26 \cdot 5\end{array}$ & $\begin{array}{l}26 \cdot 92 \\
23 \cdot 28 \\
20 \cdot 85 \\
31 \cdot 6 \\
25 \cdot 08\end{array}$ \\
\hline
\end{tabular}

TABLE VIII

FREQUENCY OF PTC-TASTE SENSITIVITY IN PATIENTS WITH GASTRODUODENAL ULCERS AND IN CONTROLS

Ulcer

Grade of Concentration

\begin{tabular}{llllllllllll}
\hline 1 & 2 & 3 & 4 & 5 & 6 & 7 & 8 & 9 & 10 & Total & $9+10$
\end{tabular}

(\%)

\begin{tabular}{|c|c|c|c|c|c|c|c|c|c|c|c|c|}
\hline $\begin{array}{l}\text { Duodenal } \\
\text { Combined } \\
\text { Duodenal and combined } \\
\text { Primary gastric } \\
\text { Controls }\end{array}$ & $\frac{-}{-}$ & $\begin{array}{l}-1 \\
\frac{1}{7}\end{array}$ & $\begin{array}{r}36 \\
4 \\
40 \\
8 \\
42\end{array}$ & $\begin{array}{r}80 \\
4 \\
84 \\
24 \\
90\end{array}$ & $\begin{array}{r}129 \\
13 \\
142 \\
25 \\
127\end{array}$ & $\begin{array}{r}78 \\
9 \\
87 \\
17 \\
43\end{array}$ & $\begin{array}{r}24 \\
1 \\
25 \\
5 \\
20\end{array}$ & $\begin{array}{r}7 \\
3 \\
10 \\
6 \\
12\end{array}$ & $\begin{array}{r}47 \\
7 \\
54 \\
10 \\
54\end{array}$ & $\begin{array}{r}82 \\
19 \\
101 \\
21 \\
116\end{array}$ & $\begin{array}{r}483 \\
61 \\
544 \\
116 \\
512\end{array}$ & $\begin{array}{l}26 \cdot 7 \\
42 \cdot 6 \\
28 \cdot 5 \\
26 \cdot 7 \\
33 \cdot 2\end{array}$ \\
\hline
\end{tabular}



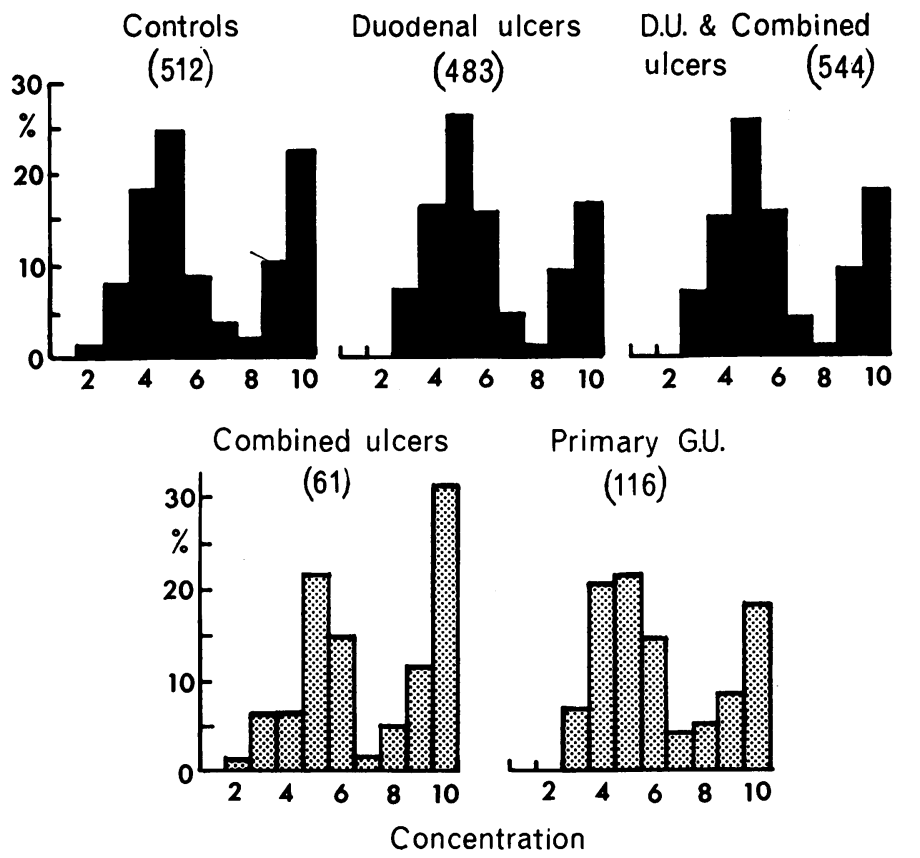

FIG. 5. Frequency of grade of phenylthiocarbamide (PTC)-taste sensitivity in patients with gastroduodenal ulcers and in controls (in \%). The shaded histograms are based on relatively smaller numbers of cases. (Figures in brackets denote number of cases.) investigated PTC-taste sensitivity in 660 patients and 512 controls. We used several solutions, of which the basic one, no. 9, had a concentration of $1: 1,000$, no. $81: 10,000$, and the rest always one-half less. No. 10 indicates people who could not taste even the basic concentration.

Table VIII and Fig. 5 give the frequency of degrees of taste sensitivity for phenylthiocarbamide. They show bimodality of the curve for patients and controls, and a reduced number of non-tasters among patients with duodenal and primary gastric ulcers. The only statistically significant difference is that between patients with duodenal ulcers and the control group (Table IX); for the other types of ulcer the results cannot be considered as final in view of the smaller size of the groups.

\section{TABLE IX}

STATISTICAL SIGNIFICANCE OF THE INCIDENCE OF PTC NONTASTERS (GRADE 9-10) IN PATIENTS WITH DIFFERENT TYPES OF ULCER

\begin{tabular}{lcccc} 
Type of Ulcer & $\begin{array}{l}\text { PTC-non-tasters } \\
(9 \text { and 10) }\end{array}$ & $\begin{array}{l}\text { PTC-tasters } \\
(1-8)\end{array}$ & $x^{\mathrm{a}}$ & $\mathrm{P}$ \\
\hline Duodenal & 129 & 354 & 4.9003 & $<0.05$ \\
$\begin{array}{l}\text { Controls } \\
\text { Duodenal and }\end{array}$ & 170 & 342 & & \\
$\quad$ combined ulcer & 155 & 384 & & \\
Controls & 170 & 342 & 2.5625 & - \\
Primary gastric & 31 & 85 & & \\
Controls & 170 & 342 & 1.7516 & -
\end{tabular}

CLINICAL MANIFESTATIONS AND SYMPTOMS FOR TYPES OF PEPTIC ULCER Clinical symptoms are conditioned mainly by the extent and localization of lesions, complications, or relationships to neighbouring organs; some signs and characteristics, however, may be genetically conditioned, too. Finally, it is not without interest to ascertain whether there are not some interrelationships among the individual signs.

We studied this question in our basic group of 1,160 patients, using punched cards.

Figure 6 gives a survey of the incidence of clinical signs for the three types of peptic ulcer. The greatest differences were in the nature of the pain, where pain on fasting predominated for duodenal ulcer cases. Absence of pain in primary gastric ulcers probably applied to acute ulcers.

More detailed processing of the data did not reveal any very marked relationships among the signs. It was possible to discern only a relationship between heartburn on the one hand, and pain on fasting, constipation, and a higher degree of acidity on the other. For duodenal and combined ulcers a relationship between blood group $\mathrm{O}$ and hyperacidity was noted.

The size of the duodenal ulcer group permitted examination of the relationship between duration of the illness and some clinical manifestations. Hyperacidity predominated even in ulcers of over 10 years' duration. Pain on fasting was more frequent with 


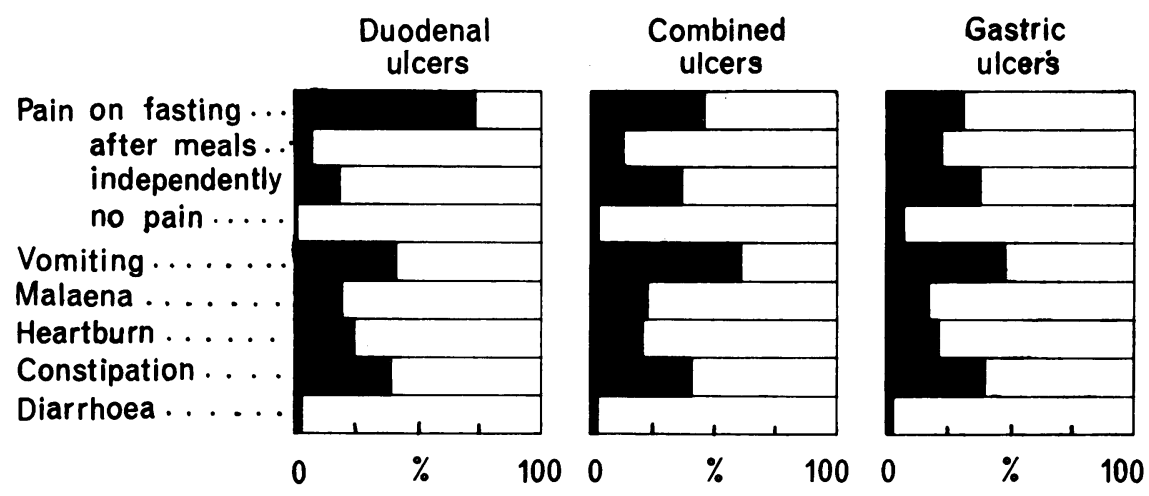

FIG. 6. Nature of pain and incidence of clinical symptoms in patients with duodenal, combined, and primary gastric ulcers. long duration of the illness, similarly vomiting, melaena, and heartburn (Table X).

SOME FURTHER OBSERVATIONS ON PATIENTS WITH PEPTIC ULCERS We examined the incidence of smoking in our group of 1,160 patients: $74 \%$ of men and $28-38 \%$ of women were smokers. This figure is somewhat higher than the estimate for the whole population and higher than in the group of 500 patients with other diseases than peptic ulcer and cancer (58.2\% for men and $25.7 \%$ for women). The difference is statistically significant for men only. Smokers showed a higher frequency of pain on fasting, heartburn, vomiting, and melaena. Some relationship between smoking and hyperacidity was also observed.

This finding agrees with the general clinical experience that smoking has an unfavourable influence on the course of ulcer disease (Doll and Jones, 1958; Hammond, Van Griethuysen, Dibeler, Sneddon, and Halligan, 1965; Kozoll and Meyer, 1964; Piper and Raine, 1959) and possibly on their genesis. In view of the differences in smoking among

TABLE $X$

DURATION OF THE DISEASE AND SOME CLINICAL CHARACTERISTICS OF DUODENAL ULCER

\begin{tabular}{lllll} 
Clinical Signs & \multicolumn{3}{l}{ Duration (years) } \\
\cline { 2 - 5 } & $1-2$ & $3-5$ & $6-10$ & $10-$
\end{tabular}

Hyperacidity

Normal acidity

$49(63.0 \%) \quad 26(60.5 \%) 27(62.8 \%) 41(60.3 \%$

Hypacidity

Anacidity

Pain: On fasting

After meals

Independently

No pain

Vomiting

Melaena

Pyrosis

Constipation

Diarrhoea

$18(22.8 \%) \quad 11(25.6 \%) \quad 13(30.2 \%) \quad 12(17.6 \%)$

$12(15.2 \%) \quad 6(13.9 \%) \quad 3(7.0 \%) \quad 14(20.6 \%)$

- - $-1 \quad-1$ - 1 (1.5\%)

$51(64 \cdot 6 \%) \quad 33(76 \cdot 7 \%) \quad 32(74 \cdot 4 \%) \quad 47(69 \cdot 1 \%)$

$7(8.9 \%) \quad 5(11.6 \%) \quad 4(9.3 \%) \quad 4(5.9 \%)$

$21(26.5 \%) \quad 5(11.6 \%) \quad 7(16.3 \%) \quad 15(22.1 \%)$

- - - $-2(2.9 \%)$

$24(30 \cdot 4 \%) \quad 16(37 \cdot 2 \%) \quad 18(41.9 \%) \quad 30(44 \cdot 1 \%)$

$8(10.1 \%) \quad 10(23.3 \%) \quad 7(16.3 \%) \quad 19(29.9 \%)$

$19(24.1 \%) \quad 13(30.2 \%) \quad 14(32.6 \%) \quad 21(30.9 \%)$

$30(38.0 \%) \quad 16(37.2 \%) \quad 23(53.5 \%) 25(36.8 \%)$

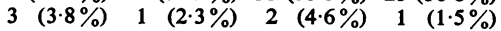

Total
43

43

68 men and women, however, it cannot be considered as the sole or main factor in the origin of ulcers.

Records of appendectomy were followed in the case histories of 1,046 patients with gastroduodenal ulcers. The incidence of this operation was found in patients with duodenal ulcer in $20 \%$, with combined in $11 \%$, and with primary gastric ulcer in $7 \%$. In the control group of 500 patients who did not suffer from peptic ulcer nor from cancer the incidence of appendectomy was $19 \%$.

For 137 patients with duodenal ulcer and appendectomy in their case histories, the distribution of clinical signs, including onset of the disease, frequency of blood groups, and degree of acidity, was practically the same as for the whole group of duodenal patients; only pain on fasting was more frequent.

In our patients with duodenal ulcer we thus cannot provide evidence of a higher incidence of appendicitis, and, on the contrary, in patients with combined and primary gastric ulcers appendicitis was encountered much more rarely than in patients with other diseases.

\section{DISCUSSION}

The clinical manifestations and characteristics of peptic ulcer are to some extent variable, and therefore the need arrives to divide them into groups with the same or similar sets of characteristics; evaluation of data for ulcer conditions as a whole leads necessarily to divergent conclusions according to which type of ulcer predominates in a given group. Consequently, clinical data and characteristics were determined and statistically evaluated for a considerable number of patients, so that material could be gained for dividing peptic ulcers into basic types. The following factors were traced: incidence of the condition, age of patients at the time of the first evidence of a lesion, clinical manifestations, case histories on smoking, appendectomy, incidence of 
ulcer conditions among closest relatives in 1,160 cases; concentration of hydrochloric acid in the gastric juice in 980 cases; frequency of blood groups in 1,964 cases; secretor status of ABH-blood group substances in saliva in 658 cases; and phenylthiocarbamide (PTC)-taste sensitivity in 660 patients suffering from peptic ulcer.

Based on the results, we suggest that peptic ulcers may be divided into duodenal, combined, and primary gastric. For duodenal ulcers, lesions appear on an average 11 years earlier than for primary gastric ulcers, hyperacidity predominates, there is a higher frequency of blood groups $\mathrm{O}$ and $\mathrm{AB}$, and of the percentage of non-secretors of $\mathrm{ABH}$ group substances in saliva, and there is better PTC-taste sensitivity. Patients report appendectomy in $20 \%$ of cases, which is more than with other types of ulcer. For primary gastric ulcers, the frequency of blood groups, secretor status, and PTC-taste sensitivity do not differ statistically from the controls.

In $18 \%$ of duodenal ulcer cases it can be expected that on an average gastric lesions will appear within 11 years, and they will thereafter turn into combined ulcers. The latter can be regarded as a subgroup of duodenal ulcers, to which they approximate in blood group frequency, secretor status and PTC-taste sensitivity; the small size of the groups did not permit statistical evaluation. Gastric lesions in these cases are localized below the angulus more frequently than in primary gastric ulcers. In both types of gastric lesion, ulcers below the angulus appear sooner and show greater acidity than ulcers above it. The average acidity is reduced for both types of gastric lesion.

Certain differences according to the type of ulcer were found in clinical manifestations but they were not very marked. An attempt to correlate the clinical symptoms and signs indicates some relationship between blood group $\mathrm{O}$ and hyperacidity, heartburn, vomiting, and melaena.

These results confirm the necessity to classify gastroduodenal ulcers into basic types which differ by their course, clinical manifestations, and in particular in the frequency of some genetically conditioned characteristics. The separation of combined ulcers renders this classification more accurate and respects the dynamics of the disease, and suggests that a more detailed examination should be made of local biochemical, morphological, and immunological conditions in the alimentary tract. Finally it also provides certain basic data for reflexions on the aetiology of peptic ulceration.

The present work, of course, cannot elucidate all obscure points of such a complicated problem as the genesis of gastroduodenal ulcer. If we speak about duodenal and gastric ulcers we are aware of the difficulty involved in defining a precise boundary between them. The purely topical aspect with the pylorus as the general boundary is not precise enough. The line of transition of the duodenal to gastric mucous membrane can be at any point in the pyloric canal (Andersson and Grossman, 1965) and thus a pyloric ulcer could, from this histological standpoint, be either duodenal or gastric. The matter is not resolved by making a special group of pyloroduodenal ulcers. This term applies to the pyloric and juxtapyloric ulcers on the duodenal and prepvloric wall, which because of their site are characterized by similar clinical manifestations (frequent pyloric stenosis etc.); this does not apply to the pathogenesis.

Johnson (1965), based on extensive material, divided gastric ulcers into three groups: a fundamentally divergent type lies above the angulus, those below it are often combined with duodenal ulcers. An important factor in classification is that of gastric acidity. In our own classification we have tried to respect the dynamics of the condition; we consider acidity to be a reflexion of the anatomical structure of the tract or the functional state of the organism. We have also found primary gastric ulcers located below the angulus, and on the contrary, gastric lesions in combined ulcers high above the angulus.

We feel that although a great deal still remains to be proved, our ideas on the aetiology of gastroduodenal ulcers can be at present summarized as follows:

Peptic ulcer is a benign, non-specific lesion of the mucous membrane and walls of those sections of the digestive tract that are exposed to the influence of active peptic gastric juices. Its cause lies in a disturbance of balance between the aggressive and protective processes in the alimentary tract. An ulcer forms through the interplay of immediate causes and the intrinsic reactivity of the organism (predisposition). Causes or evoking factors are many, they are non-specific, and for the most part external. Inner reactivity is conditioned by many factors, of which some are genetically based.

The mucous membranes of the stomach and duodenum are exposed to various assaults tending to cause minor and usually temporary lesions, haemorrhages, erosions, and necroses. Physical, thermal, chemical, and mechanical influences are likely to be more prevalent in the stomach than in the duodenum. It is a plausible assumption that a large part is also played by changes in the blood supply to the wall of the tract, whether in congestion, in portal hypertension (Fischer and Snyder, 1965), in cardiopulmonary disease, and possibly in burns, or more frequently in ischaemia (Shay and Sun, 1964) due to 
spasms of vasomotor and largely corticovisceral origin. Viscerovisceral reflexes may also be involved, manifesting themselves both in circulatory disturbances and chemical gastric changes. At the initial stage of ulcer formation, stress affects are exerted by the corticovisceral route and are manifested in the blood supply to the mucous membrane. Their secretory component can act almost simultaneously in affecting the quality of mucus and in blocking healing processes. The effect of stress (Selye, 1946; Rausch-Stroomann, 1965; Andresen and Clausen, 1964) is conditioned by the intensity of the stimulus and the permanent or immediate receptivity of the individual.

Acute lesions have their common features (Spira, 1965; Straub and Schornagel, 1958) whether they be of corticovisceral origin (Foltz, 1964), Cushing ulcers with injury to the central nervous system (Feldman and Birnbaum, 1965), Curling's ulcers connected with burns (Abramson, 1964), severe injuries and disorders of various organs (Tokoro, 1957), the administration of drugs with local irritating effects (Menguy, 1965), or ulcers originating under similar conditions, such as those constructed when inducing experimental ukcers. They may be located in the duodenum or stomach.

From acute, non-specific and commonly occurring lesions there may develop, under suitable conditions, which are individual and can change rapidly with time for the same individual, a large ulcer and a chronic ulcer. The causes lie in the duration and intensity of the stimuli that induced the acute lesion and in local and individual conditions, which change very quickly in the course of time. Local factors also decide whether there is greater probability for a given individual to incur ulceration in the duodenum or in the stomach.

Chronic ulcers can be divided in two main groups, primary gastric ulcers and duodenal ones, to which a subgroup of combined ulcers may be appended. These two groups differ in the time of onset and clinical manifestations, and in the internal conditions rendering the development of an ulcer possible.

As to clinical signs, among the leading factors for duodenal ulcers is hyperacidity, which raises the aggressive power of juices in relation to the mucosa and may also physically denature the protective mucus. The quality of mucus is presumably in some way influenced by the absence of $\mathrm{ABH}$ group substances. A factor linked to blood group $O$ is not known. Possibly it is biochemical, or there is a linkage between the gene for the group and the extent of the secretory area and hence the degree of acidity, or finally, it has to do with the structure of the nervous system, functions of nervous regulation, and so on.
One of the factors promoting the transition of an $\stackrel{\overrightarrow{0}}{\stackrel{\vec{P}}{2}}$ acute ulcer into a chronic one is the state of the mucosa (Massewitsch, 1965; Oi et al., 1959). One can assume that in early life the duodenal and stomach membranes are intact. Change in time proceeds in an oral direction, involving degeneration के and intestinal metaplasia (Planteydt and Willighagen, 1960) be it progressive inflammation, effects of harmful agents, or immunological processes.

On a mucous membrane thus altered ulcers develop in the stomach, progressively at the sites to which mucosal changes have proceeded. Here the mechanism stressed by Dragstedt, and regarded by him as the sole one, may be operative, that is, pyloric stenosis, stagnation of content, and hyperacidity. In this way combined ulcers develop, having some signs, especially the genetically conditioned, in common with the duodenal.

Chronic primary gastric ulcers form on altered, atrophic, or degenerating mucous membrane, the state of which is probably reflected in the composition of mucus and a reduced regeneration of epithelial cells. Here there is no connexion with the absence of group substances and the correlation with group A frequency, referred to by some authors (not proved in our material), is doubtful. More probable are immunological processes and biochemical and enzymatico-histochemical changes such as are found with atrophic gastritis.

This account of the aetiology of gastroduodenal ulceration is intended as a basis for further examination of genetic factors and for more detailed study of local conditions and processes in the stomach and duodenum; it also aims at drawing attention to the differentiation exhibited by the manifestations of ulcer disease.

\section{SUMMARY}

An attempt has been made to classify gastroduodenal ulcer by a statistical survey of various clinical and genetic factors in 1,160 ulcer subjects and in a similar number of controls. Ulcer incidence, age of onset of symptoms, smoking habits, frequency of appendicectomy, family history, acid secretory status, and the association with various blood groups, presence of $\mathrm{ABH}$ blood group substances in the saliva and to taste phenylthiocarbamide (PTC) was investigated. From these data it is suggested that peptic ulcers should be classified as duodenal, combined, and primary gastric ulcers.

Duodenal ulcers appear 11 years earlier than gastric and are associated with hyp eracidity, with higher frequencies of $\mathrm{O}$ and $\mathrm{AB}$ blood groups, with an increased proportion of non-secretors of $\mathrm{ABH}$ substances in the saliva, and with better PTC taste 
sensitivity. The frequency of appendicecto my greater than in other types of ulcer but no greater than in control patients.

About $18 \%$ of patients with duodenal ulcer subsequently develop gastric ulcers within 11 years of the onset of symptoms and ulcers become 'combined'. These ulcers are usually situated distal to the angulus and show similar clinical and genetic characteristics to duodenal ulcer.

The clinical differences between the various types of ulcer are not marked save that patients with group $\mathrm{O}$ blood groups tend to develop hyperacidity, heartburn, vomiting, and melaena more commonly than other groups.

The aetiology of the various types of ulcer is reviewed.

We wish to thank Professor J. Mašek, M.D., D.Sc., and Professor J. Hořejší, M.D., D.Sc., for their valuable advice and friendly encouragement, and Miss J. Machová and Mr. J. Košař for assistance with the graphic presentation of the material.

\section{REFERENCES}

Abramson, D. J. (1964). Curling's ulcer in childhood. Surgery, 55 , 321-336.

Aird, I. (1959). The association between the ABO blood groups and gastro-intestinal disease. Gastroenterologia (Basel), 92, 95-99.

Andersson, S., and Grossman, M. I. (1965). Profile of $p \mathrm{H}$, pressure, and potential difference at gastroduodenal junction in man. Gastroenterology, 49, 364-371.

Andresen, P., and Clausen, J. (1964). Gastric 'stress' ulceration in myocardial infarction. Acta med. scand., 176, 467-472.

Billington, B. P. (1965). Observations from New South Wales on the changing incidence of gastric ulcer in Australia. Gut, 6, 121-133.

Buckwalter, J. A. (1962). Peptic ulcer and the blood groups. Ann. N.Y. Acad. Sci., 99, 81-88.

Caldwell, R. C., and Pigman, W. (1965). The carbohydrates of human submaxillary glycoproteins in secretors and non-secretors of blood group substances. Biochim. biophys. Acta (Amst.), 101, 157-165.

Card, W. I. (1961). Clinical application of the physiology of the stomach. Gut, 2, 87.

Clarke, C. A. (1959). Distribution of ABO blood groups and the secretor status in duodenal ulcer families. Gastroenterologia (Basel), 92, 99-103.

Demole, M., and Ulman, K. (1964). Les ulcères gastriques de dénutrition. Ibid., 102, 198-210.

Doll, R., and Jones, F. A. (1958). Smoking and peptic ulcer. Schweiz. Z. allg. Path., 21, 309-313.

- Drane, H., and Newell, A. C. (1961). Secretion of blood group substances in duodenal, gastric, and stomal ulcer, gastric carcinoma, and diabetes mellitus. Gut, 2, 352-359.

Feldman, S., and Birnbaum, D. (1965). The effect of brain stimulation on gastric secretion. Israel J. med. Sci., 1, 415-422

Fischer, J. E., and Snyder, S. H. (1965). Increased gastric synthesis of histamine: a possible mechanism for the gastric acid hypersecretion following portacaval shunt. Fed. Proc., 24, 1334-1340.

Foltz, E. L. (1964). Neurophysiological mechanisms in production of gastrointestinal ulcers. J. Amer. med. Ass., 187, 413-417.

Frankel, A., and Kark, A. E. (1965). Gastric ulcer. Amer. J. Gastroent., 44, 26-39.

Glass, G. B. J., Stephanson, L., and Rich, M. (1956). Paper-electrophoretic analysis of gastric juice in health and disease, and its physiological and clinical significance. Gastroenterologia (Basel), 86, 384-395.

Gullberg, R., and Olhagen, B. (1959). Electrophoresis of human gastric juice. Nature (Lond), 184, 1848-1849.

Hammond, E. C., Van Griethuysen, T. H., Dibeler, J. B., Sneddon, A. M., and Halligan, W. (1965). Smoking habits and disease in New York State. N.Y. St. J. Med., 65, 2557-2561.
Hanley, W. B. (1964). Hereditary aspects of duodenal ulceration: serum-pepsinogen level in relation to $\mathrm{ABO}$ blood groups and salivary ABH secretor status. Brit. med. J., 1, 936-940.

Jirásek, V., and Gregor, O. (1964). Některé genealogické problémy vredové choroby. (Some genealogical problems of ulcer disease). Acta Univ. Carol. Med. (Praha), suppl. 18, 177-183.

Johnson, H. D. (1965). Gastric ulcer: classification, blood group characteristics, secretion patterns and pathogenesis. Ann. Surg. 162, 996-1004.

Kaplan, A. R., Fischer, R., Glanville, E., Powell, W., Kamionkowski, M., and Fleshler, B. (1964). Differential taste sensitivities in duodenal and gastric ulcer patients. Gastroenterology, 47, 604-609.

Kout, M. (1959). Bestimmung der Blutgruppen $\mathbf{A}_{1} \mathbf{A}_{2} B O$, MNS, P, $\mathrm{Rh} / \mathrm{Hr}$, Kell und Duffy in der Prager Bevölkerung. Blut, 5 , 205-208.

Kozoll, D. D., and Meyer, K. A. (1964). Obstructing duodenal ulcers: general factors influencing incidence and mortality. Arch. Surg., 88, 793-799.

Kubícková, Z., and Veselý, K. T. (1966). Die Blutgruppen $\mathbf{A}_{1} \mathbf{A}_{2} \mathrm{BO}$ $\mathrm{Rh}_{0}$ (D), die Ausscheidungsfähigkeit der ABH-Substanzen und die Ulcuskrankheit. Gastroenterologia (Basel), 105, 1-11.

Langman, M. J. S., and Doll, R. (1965). ABO blood group and secretor status in relation to clinical characteristics of peptic ulcer. Gut, 6, 270-273.

Lazarus, S. (1964). Perforated peptic ulcer in Israel. Ibid., 5, 590-596.

Lazovskij, J. M. (1947). Funktsionalnaya morphologiya sheludka v norme i patologii. Izd. Akad. Med. Nauk. S.S.S.R., (Moscow), pp. 367.

Levrat, M., Larbre, F., and Richard, M. (1954). Ulcère gastroduodénal à début juvenile avec hérédité ulcéreuse double dans les lignes paternelles et maternelles. Arch. Mal. Appar. dig., 43, 1001-1010.

Mašek, J. (1956). Nové poznatky o patofysiologii a therapii vředové choroby. Státní Zdravotnické Nakl., Prague.

Massewitsch, C. (1965). Die Ergebnisse paraleller Saugbiopsie der Magen- und Duodenalschleimhaut bei Ulcusckrankheit und chronischer Gastritis. Dtsch. Z. Verdau.-u. Stoffwechselkr, 25, 226-229.

May, J. M. (1958). Report on the geography of peptic ulcer. Schweiz. Z. allg. Path., 21, 169-209.

McConnell, R. B. (1960). Heredity in gastroenterology: a review. Gut, 1, 273-284.

McHardy, G. (1962). Gastric ulcer problems. Ann. N.Y. Acad. Sci., 99, 89-103.

Menguy, R. (1965). Use of aspirine. More known of its uses, side effects. Med. Trib., 6, 13 .

Newman, E., Naifeh, G. S., Auer, J. E., and Buckwalter, J. A. (1961). Secretion of ABH antigens in peptic ulceration and gastric carcinoma. Brit. med. J., 1, 92-94.

Oi, M., Oshida, K., and Sugimura, S. (1959). The location of gastric ulcer. Gastroenterology, 36, 45-56.

Piper, D. W., and Raine, J. M. (1959). Effect of smoking on gastric secretion. Lancet, 1, 696-698.

Placer, Z., Roubal, Z., and Vokáč, V. (1958). The action of gastric mucus and some sulphonated compounds on the development of experimental gastric ulcers in rats. Rev. Czech. Med., 4, 111-124.

Planteydt, H. T., and Willighagen, R. G. J. (1960). Enzyme histochemistry of the human stomach, with special reference to intestinal metaplasia. J. Path. Bact., 80, 317-323.

Rausch-Stroomann, J. G. (1965). Fragen des Steroidulcus. Dtsch. $Z$. Verdau.-u. Stoffwechselkr, 25, 281-300.

Roberts, J. A. F. (1957). Blood groups and susceptibility to disease. Brit. J. prev. soc. Med., 11, 107-125.

Schade, R. O. K. (1958). The morbid anatomy of peptic ulceration. Schweiz. Z. allg. Path. B., 21, 372-388.

Selye, $H$. (1946). The general adaptation syndrome and the diseases of adaptation. J. clin. Endocr., 6, 117-230.

Shay, H., and Sun, D. C. H. (1964). Etiology and pathology of gastric and duodenal ulcer. In Gastroenterology, edited by $\mathrm{H}$. L. Bockus, 2nd ed., vol. 1, pp. 420-465. Saunders, Philadelphia and London.

Sievers, M. L. (1959). Hereditary aspects of gastric secretory function: race and ABO blood groups in relationship to acid and pepsin production. Amer. J. Med., 27, 246-255.

Spira, J. J. (1965). Pathogenesis of gastric ulceration. Lancet, 2, 182-183.

Straub, M., and Schornagel, H. E. (1958). General aetiology of gastroduodenal ulcer. Schweiz. Z. allg. Path. B., 21, 242-259. 
Susser, M., and Stein, Z. (1962). Civilization and peptic ulcer. Lancet, $1,115-119$.

Tokoro, Y. (1957). The correlation of gastroduodenal ulcers. (The lesions of other organs in the course of gastroduodenal ulcers: gastroduodenal ulcer and its background). Acta path. Jap., 7, 253-311.

Veselý, K. T. (1964). Beitrag zur Ätiopathogenese der Gastroduodenalgeschwüre. Dtsch. Z. Verdau.-u. Stoffwechselkr., 24, 241-255.
(1966). Peptický gastroduodenální vřed ve světle novějß̌hic poznatků. Dissert, Prague.

Watkinson, G. (1960). The incidence of chronic peptic ulcer found at necropsy. A study of 20,000 examinations performed in Leeds in 1930-1949 and in England and Scotland in 1956. Gut, 1, 14-30.

Wilson, E. B. (1962). Note on the epidemiology of peptic ulcer. Proc. nat. Acad. Sci. (Wash.), 48, 1924-1927. 